\title{
PR Management of BP Oil Spill on Gulf of Mexico-A Strategic Communication Approach
}

\author{
Kwesi Atta Sakyi \\ B.A. (Hons.) Ghana MPA (summa cum laude) (Head-Research) \\ ZCAS University Dedan Kimathi Road, Lusaka, Zambia
}

\begin{abstract}
Disaster management is cardinal in supply chain management as well as in strategic communication and public relations. This paper examines the BP Oil spill on the Gulf of Mexico in 2010 and explores how rapidly growing social media comes in handy in getting suitable communication to targeted publics. This paper makes the case that traditional news media has become obsolete as it is an outlet for a select elite who massage the content of news. This paper examines the context of the primary and secondary messages which were sent out during the whole episode as well as how best the communication should have been handled strategically. The paper relies on secondary sources to review the case and ends by making recommendations.
\end{abstract}

Key Words: public relations, strategic communications, BP, disaster response, social media

\section{INTRODUCTION}

In April 2010, a BP Oil rig in the Gulf of Mexico area about 42 miles from Louisiana exploded when Transocean, an outsourced contractor of BP's device failed to cap an underwater pipe which was 5000 feet from the surface of the ocean in the Atlantic Ocean. The explosion killed eleven people and the news grabbed headlines all around the world (Smithsonian.ocean, 2010) From the start of the spillage in April 2010 to $15^{\text {th }}$ July 2010 when the spillage was finally capped, it was estimated that about 3.19 million barrels of oil was spilled, the largest in history as it was said to be about five or six times the spill by Exxon Mobil off Alaska earlier on in 1984 (Smithsonian.ocean, 2010).

At the time, BP used chemicals to dissolve the oil as well as the use of floating oil booms to clean the slick. Also thousands of workers were employed to clean the spill on the shores. Observers were worried that it took eighty seven days (87) or three months to overcome the technical problem. The damage done to marine life and the reputation of BP was incalculable (Smithsonian.ocean, 2010). According to Watson (2015) BP was made to make a settlement of eighteen billion, seven hundred million dollars (18.7 billion dollars), which was the largest corporate settlement in the history of the US at that time. 


\section{THEORETICAL FRAMEWORK}

Figure 1: Stakeholders in BPs Crisis Management Arena

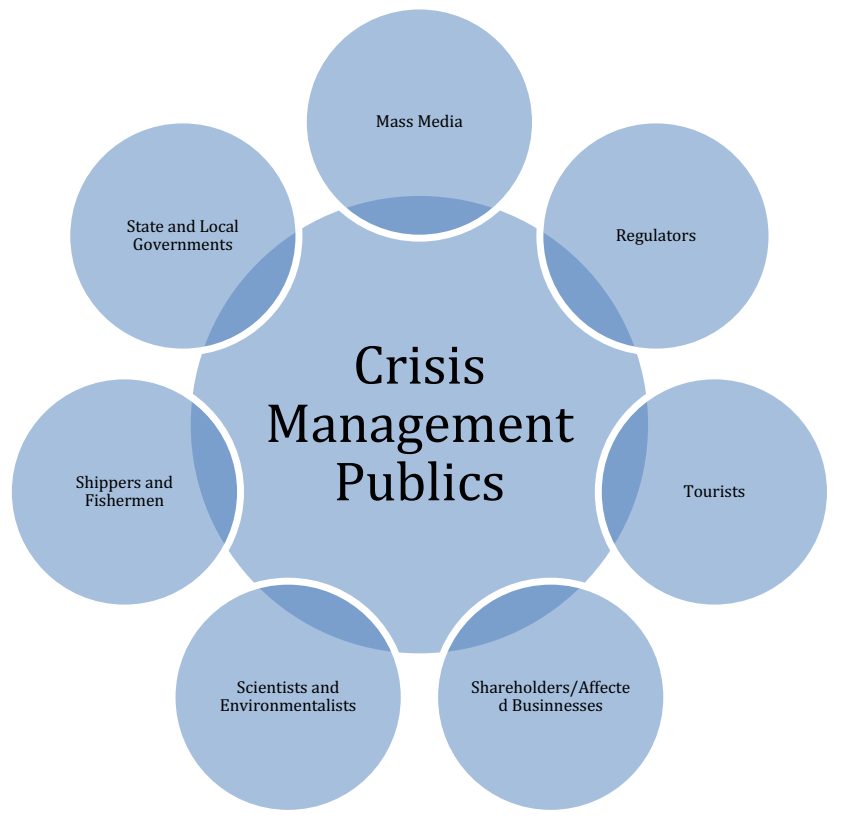

Figure 2: Factors to consider in targeting publics

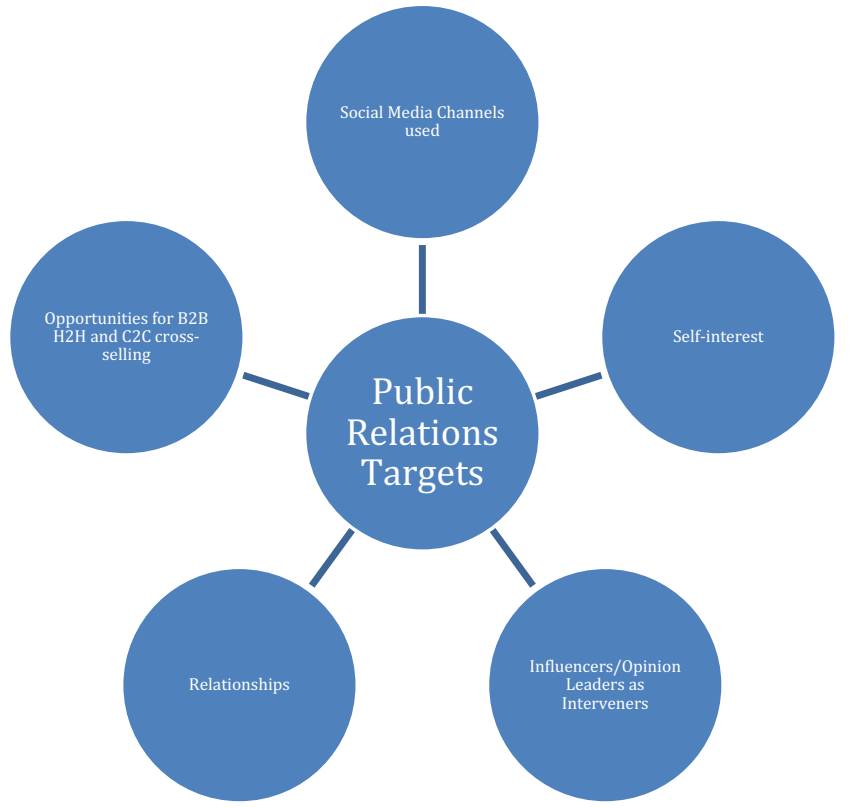


Figure 3: What BP did wrong

- Diversionary tactics
- Delays
- Manipulation of media by hiring writers and bloggers as mouthpieces
- Hiding facts
- Being angry and unavailable with no communication

(Sources: Adapted from several sources online. See References below)

Figure 4: Power and advantages of Social Media

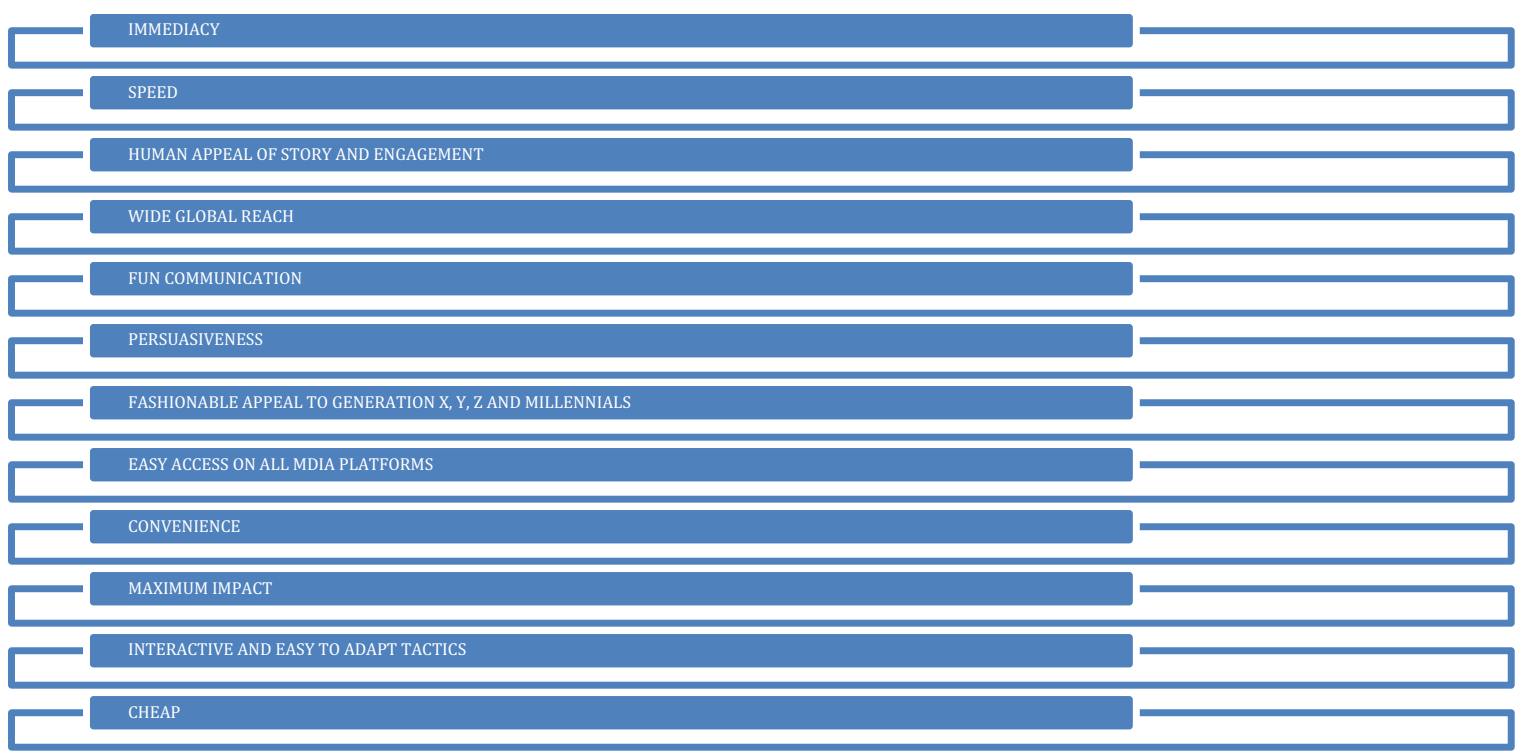

(Sources: Several)

\section{Tactics}

\section{ANALYSIS OF PR ISSUES}

Initially BP used diversionary tactics of not accepting blame and responsibility by playing the macho or Tough Guy culture. It did not help that the Federal Management of Minerals Board was the same as the regulator in charge of overseeing safety and also the one issuing Licences for exploration and collecting royalty payments. That compromised oversight functions because there was no segregation of duties. On that score, BP had a point by exploiting the loophole (Watkins, 2010)

\section{Social Media and Technologies Employed}

Initially, BP failed as it resorted to high profile press conferences which kept journalists waiting for hours and days on end to get news scoops. Many things could have been communicated straightaway via social media without fanfare and extra cost. It was when the 
situation became very bad with no end in sight to the spill that BP engaged the services of content writers, bloggers, search engines and other ICT technologies to combat what looked like a scourge plaguing them (Rate, 2010)

\section{Successes and Failures}

Watson (2015) noted that BP had in place a questionable and faulty PR system which was not ready to own up to the truth.

Corkindale (2010) wrote that the BP oil spill showed that BP lacked sterling leadership at the time, unlike the high leadership direction shown during the 9/11 period. She claimed that the CEO of BP, Tony Hayward, took unnecessary risks, was arrogant, and he did not listen to advice nor seek one.

Corkindale (2010) pointed out that crises management exposes how dysfunctional an organization is with regard to its culture, communication system, general systems in place, and its leadership style. Corkindale (2010) advised that during crisis leaders should avoid coming up with spins or concocted stories or massaging the facts or telling the truth about things which never happened. Nevertheless, it must be observed that disasters of that magnitude can throw any leader off balance to act sometimes irrationally.

She also observed that leaders should take responsibility and avoid playing the blame game or deflecting blame to others by passing the buck. Lastly, Corkindale (2010) advised that leaders should know that they are serving the interest of the people and not their own self-interest. Be that as it may, it may not be right to be judgemental as people differ and situations should be evaluated in context. However, Corkindale (2015) therefore called for servant-leader type of leadership in all situations. This can be disputed because leadership is a function of many variables including personality, tasks, stakeholders, jurisdiction, culture, expectations, context, and many other factors.

\section{PRIMARY MESSAGES}

The primary message BP sent out was that the fault was not theirs but caused by the faulty technology of their sub-contractor, Transocean. It was totally wrong and it did not wash well with the public because it was a question of the famous Principal-Agent dilemma whereby all actions and inactions of the agent should be blamed on the Principal or Owner who hired the Agent. Shareholders bought shares by putting their trust in the BP management team. The team should have done due diligence before contracting Transocean. It could have been that some insider trading or undue influence could have been exerted in awarding the contract to Transocean. That is a conjecture. Besides, technical failures do occur despite stringent quality assurance measures because human errors can occur.

\section{SECONDARY MESSAGES}

After many complaints from regulators and the public, BP hired the services of spin-doctors to do their dirty work for them to salvage their lost reputation. Watson (2015) reported that the CEO gaffe of, "I'd like my life back" was not only arrogant but rubbing salt into injury. Thereafter, Rate (2010) wrote that BP engaged search engines and bloggers to do damage limitation strategy for them by ensuring that all online searches using keywords will pop up BP sites first so that people would see how caring and enthusiastic BP was in assisting victims. That was unethical and massaging the truth by using money to gain online influence. Rate (2010) reported that BP was paying about ten thousand dollars a day to get those search engines to their advantage. 
At the time, BP was said to be worth 115 billion dollars. BP's online sites showed how it had given 25 million dollars to help Tourism in the affected area, and also to help animal conservationists as well as Corporate Social Responsibility projects to re-employ thousands of laid-off workers to do the cleaning up of the oil spill. Rate (2010) reported that many of those workers fell ill but their stories did not get much reported. BP managed to get some media blackout on some news which would be detrimental to its reputation.

That was seen to be unethical and against the Freedom of Information Act. It is tantamount to misprision of treason whereby a citizen holds on to information which would be helpful to the state if it is disclosed. A State Governor from Florida was also reported to have visited the damaged coast and he said he did not see much damage. Was that a paid hatchet job or a networked influence?

\section{RECOMMENDATIONS}

- All MNCs should be social-media au fait or savvy to deal squarely with cataclysmic catastrophes such as that of BP by dealing directly with the publics on H2H (human- tohuman) basis instead of the roundabout and convoluted old-fashioned mass media which targets passive audiences instead of reaching active and interested publics.

- MNCs should engage tech-savvy young bloggers to get out in the open their engagement messages and communications for them

- CEOs of giant MNCs should try to be humane and not arrogant

- MNCs should put in place Public Relations Strategic and Contingency plans so that they are not caught off guard

\section{CONCLUSIONS}

The BP case of the oil spill off the coast of Gulf of Mexico in 2010 informs PR practitioners that it is better to come out in an honest, straightforward and remorseful manner than play hide and seek and try to throw dust in the eyes of the public. The CEO at the time, Tony Hayward, behaved irresponsibly by saying he ought to get his life back without having or showing empathy for millions of people who were directly affected. Of course he was human and tempers could have been frail due to the excessive media pressure. However, he could have shown a human side by taking to Twitter or Instagram to bond with the major publics and constituents who could be influencers or intervening publics to carry his feelings with speed in a viral manner.

We should not underestimate the power of Social Media because the traditional conservative media is now outmoded and ineffective because in some cases they act to the scripts written for them by their media moguls and owners who massage the media and decide what we should hear or see on TV or on radio. Social media is flexible, instant, direct, personable, reliable, affordable, and it can carry podcasts and rebroadcasts. Also it is fun and entertainment.

\section{References}

Corkindale, G. (2010) Five leadership lessons from the BP oil spill [Online]

https://hbr.org/2010/06/five-lessons-from-the-bp-oil-spill

Rate, B. (2010) Spinning the spill of BP's Public Relations ballet [Online] www.pbs.org/what/need-to-know/environment/spinning-the-spill-bps-pr-ballet/1460/

Smithsonian.ocean (2010) Gulf oil spill [Online] Retrieved from https://ocean.si.edu/conservation/gulf-oil-spill

Watkins, M (2010) The Gulf oil spill: A Classic failure of Systems Leadership [Online] Retrieved from https://hbr.org/2010/05/the-gulf-oil-spill-a classic-f

Watson, D. (2015) 5B of BP's Gulf oil spill blunders [Online] Retrieved from https://www.prdaily.com/5-of-bps-gulf-oil-spill-blunders 


\begin{tabular}{|c|c|c|c|}
\hline $\begin{array}{l}\text { Brown, D.L., } \\
\text { Vetterlein, A. \& } \\
\text { Roemer-Mahler, A. } \\
(2010)\end{array}$ & $\begin{array}{l}\text { Theorizing Transnational } \\
\text { Corporations and Social } \\
\text { Actors: An Analysis of } \\
\text { Corporate Motivations }\end{array}$ & $\begin{array}{l}\text { Business and Politics Vol. } 2 \\
\text { No. } 1,2015,9 \text { July }\end{array}$ & \\
\hline Boothby, F. & $\begin{array}{l}\text { Social Media Best Practice } \\
\text { Guide }\end{array}$ & & $\begin{array}{l}\text { http://usefulsocialmedia.c } \\
\text { om/assets/pdf/USMBriefi } \\
\text { ng.pdf }\end{array}$ \\
\hline $\begin{array}{l}\text { Carroll, A.B. \& } \\
\text { Bucholtz, A.K. (2003) }\end{array}$ & $\begin{array}{l}\text { Business and Society Ethics } \\
\text { and Stakeholder } \\
\text { Management ( } 5^{\text {th }} \text { ed.) }\end{array}$ & $\begin{array}{l}\text { Australia: Thomson South } \\
\text { Western }\end{array}$ & \\
\hline $\begin{array}{l}10 \text { Must Haves for } \\
\text { Your Social Media } \\
\text { Policy }\end{array}$ & $\begin{array}{l}10 \text { Must Haves for Your } \\
\text { Social Media Policy }\end{array}$ & & $\begin{array}{l}\text { http://mashable.com/200 } \\
\text { 9/06/02/social-media- } \\
\text { policy-musts/ }\end{array}$ \\
\hline Coombs, W.F. (2007) & $\begin{array}{l}\text { Crisis Management and } \\
\text { Communications }\end{array}$ & $\begin{array}{l}\text { Institute for Public } \\
\text { Relations } 2007\end{array}$ & $\begin{array}{l}\text { www.instituteforpr.org/to } \\
\text { pics/crisis-management- } \\
\text { and-communications/ }\end{array}$ \\
\hline Cornelissen, J. (2008) & $\begin{array}{l}\text { Corporate Communication } \\
\text { Guide to Theory and } \\
\text { Practice }\end{array}$ & $\begin{array}{l}\text { Los Angeles, C.A.: Sage } \\
\text { Publishers }\end{array}$ & \\
\hline \multirow[t]{2}{*}{$\begin{array}{l}\text { Corporate Social } \\
\text { Responsibility (2014) }\end{array}$} & $\begin{array}{l}\text { Encyclopedia for Business } \\
\text { ( } 2^{\text {nd }} \text { ed.) }\end{array}$ & & $\begin{array}{l}\text { http://www.referenceforb } \\
\text { usiness.com/management } \\
\text { /comp-de/aCSR/actual }\end{array}$ \\
\hline & $\begin{array}{l}\text { Crisis Communication } \\
\text { Plan: A Public Relations } \\
\text { Blueprint }\end{array}$ & & $\begin{array}{l}\text { https://www3.niu.edu/ne } \\
\text { wsplace/crisis.html }\end{array}$ \\
\hline Coombs, W.T. & $\begin{array}{l}\text { Protecting Organizational } \\
\text { Reputation during a crisis: } \\
\text { The Development and } \\
\text { Application of Situational } \\
\text { Crisis Communication } \\
\text { Theory }\end{array}$ & $\begin{array}{l}\text { Corporate Reputation } \\
\text { Review Vol. 10, No. 3, pp. } \\
163-176\end{array}$ & \\
\hline Dougal, E. (2008) & & $\begin{array}{l}\text { Issues Management } \\
\text { Institute of Public Relations } \\
\text { December, 2008, pp.153- } \\
219\end{array}$ & \\
\hline $\begin{array}{l}\text { Goodman, M., \& } \\
\text { Hirsch, P. (2010) }\end{array}$ & $\begin{array}{l}\text { Strategic Adaptation for } \\
\text { Global Practice in } \\
\text { Corporate Communication: } \\
\text { Strategic Adaptation for } \\
\text { Global Practices }\end{array}$ & $\begin{array}{l}\text { New York, N.Y.: Peter Lang } \\
\text { pp. 141-153 }\end{array}$ & \\
\hline Laskin, A.V. (2011) & $\begin{array}{l}\text { How Investor Relations } \\
\text { Contribute to the } \\
\text { Corporate Bottom Line }\end{array}$ & $\begin{array}{l}\text { Journal of Public Relations } \\
\text { Research Vol. 23, No. } 3 \text { pp. } \\
302-324\end{array}$ & \\
\hline $\begin{array}{l}\text { Lux, S.T., Crook, R. \& } \\
\text { Woehr, D.J. (2011) }\end{array}$ & $\begin{array}{l}\text { Mixing Business with } \\
\text { Politics: A Meta-Analysis of } \\
\text { the Antecedents and } \\
\text { Outcomes of Corporate } \\
\text { Political Activity }\end{array}$ & $\begin{array}{l}\text { Journal of Management } \\
\text { Vol. 37, No. } 1 \text { January } \\
\text { 2011, pp.223-247 }\end{array}$ & \\
\hline Patterson, J. (2015) & $\begin{array}{l}\text { Multinationals have } \\
\text { become Social and Political } \\
\text { Actors who need to } \\
\text { address publics in a } \\
\text { constant flow of } \\
\text { communication }\end{array}$ & & \\
\hline
\end{tabular}




\begin{tabular}{|c|c|c|c|}
\hline Smith, R. (2012) & $\begin{array}{l}\text { Analyzing the } \\
\text { Organization's Strategic } \\
\text { Planning for Public } \\
\text { Relations }\end{array}$ & N.Y.: Routledge Press & \\
\hline $\begin{array}{l}\text { Smudde, P. M. \& } \\
\text { Courtright, J. (2011) }\end{array}$ & $\begin{array}{l}\text { A Holistic Approach to } \\
\text { Stakeholder Management: } \\
\text { A Rhetorical Foundation }\end{array}$ & $\begin{array}{l}\text { Public Relations Review } \\
\text { Vol. } 37 \text { No.2, pp.137-144 }\end{array}$ & \\
\hline $\begin{array}{l}\text { Straubhaar, J., \& } \\
\text { LaRose, R. (2010) }\end{array}$ & $\begin{array}{l}\text { Media Now: } \\
\text { Communications Media in } \\
\text { the Information Age }\left(3^{\text {rd }}\right. \\
\text { ed.) }\end{array}$ & $\begin{array}{l}\text { Connecticut: Wadsworth } \\
\text { Publishing pp. 324-368 }\end{array}$ & \\
\hline $\begin{array}{l}\text { Shum, P.K. \& Yam, S.L. } \\
\text { (2011) }\end{array}$ & $\begin{array}{l}\text { Ethics and Law: Guiding } \\
\text { the Invisible Hand to } \\
\text { Correct Corporate Social } \\
\text { Responsibility } \\
\text { Externalities }\end{array}$ & $\begin{array}{l}\text { Journal of } \\
\text { Business } \\
\text { Ethics 2011, } \\
\text { Vol. 98, } \\
\text { pp.549-571 }\end{array}$ & \\
\hline Watson, D. (2015) & $\begin{array}{l}5 \text { of BPs biggest Gulf oil } \\
\text { spill PR blunders }\end{array}$ & $\begin{array}{l}\text { Ragan's PR Daily, } 9 \text { July } \\
2015\end{array}$ & $\begin{array}{l}\text { https://www.prdaily.com/ } \\
\text { 5-of-bps-biggest-gulf-oil- } \\
\text { spill-pr-blunders }\end{array}$ \\
\hline WikiHow.com & $\begin{array}{l}\text { How to write a Press } \\
\text { Release }\end{array}$ & Wiki-How & $\begin{array}{l}\text { http://www.wikihow.com } \\
\text { /Write-a-Press-Release }\end{array}$ \\
\hline Service.prweb.com & $\begin{array}{l}\text { How to Write a Successful } \\
\text { News Release, PRWeb }\end{array}$ & & $\begin{array}{l}\text { http://service.prweb.com/ } \\
\text { learning/article/how-to- } \\
\text { write-a-successful-news- } \\
\text { release/ }\end{array}$ \\
\hline
\end{tabular}

